\title{
Karakter Morfologi dan Sitologi Bunga Pepaya Merah Delima
}

\section{Morphological and cytological characters flower of Papaya Merah Delima}

\author{
Noflindawati ${ }^{1,2}$, Aswaldi Anwar ${ }^{2}$, Yusniwati ${ }^{2}$ dan Agus Sutanto ${ }^{1}$ \\ 1) Balai Penelitian Tanaman Buah Tropika \\ ${ }^{2)}$ Fakultas Pertanian Universitas Andalas \\ *Koresponden noflindawariacik@gamail.com
}

\begin{abstract}
The papaya plant has three types of flowering, male flowers, female flowers, and perfect flower (hermaphrodite). The difference in interest affects the shape of the resulting fruit. This study aimed to characterize morphology and cytology of papaya flowers. The study was conducted in Tropical Fruit Research Institute at Solok and Laboratory of SPT at the Biology Department of the Faculty of Mathematics and Natural Sciences, Andalas University, Padang, West Sumatra. The research material uses papaya flowers Merah Delima variety from KP. Aripan Balitbu Troipka. The results showed the male flowers of male plants were smaller than the male flowers of the perfect plant. The difference of hermaphrodite flower of pentandria with hermaphrodite elongata flower, among others, the number of stamens, the length of the stem and the size of the ovary. Hermaphrodite pentandria has a number of stamens 5 while elongata has stamens 10
\end{abstract}

Keyword : female flower, hermaprodite flowers, male flower, papaya

\section{Pendahuluan}

Tanaman pepaya merupakan tanaman dioceous, namun juga ada gynodioceous, terdapat tiga jenis tanaman berdasarkan tipe pembungaan yaitu tanaman dengan bunga jantan, tanaman dengan bunga betina dan tanamaan dengan bunga sempurna (hermaprodit).Tanaman pepaya mempunyai sifat pembungaan yang berbeda dengan tipe pembungaan tanaman buah lainnya. Pepaya tipe dioecious mempunyai ekspresi seks bunga betina (pistillate) pada pohon betina dan bunga jantan (staminate) pada pohon jantan. Pepaya tipe gynodioecious mempunyai ekspresi seks bunga betina dan bunga hermafrodit pada pohon hermafrodit dan bunga jantan pada pohon jantan (Nakasone 1986; Villegas 1997; Magdalita dan Mercado 2003; Ming et al. 2007;2010; Jimenez, 2014).

Bunga merupakan alat reproduksi seksual. Bunga dikatakan lengkap apabila mempunyai daun kelopak, daun mahkota, benang sari, putik atau daun buah. Bunga terdiri atas bagian fertil, yaitu benang sari dan daun buah, serta bagian yang steril yaitu daun kelopak dan daun mahkota (Tjitrosoepomo 2005; Rosanti, 2013). Definisi bunga menurut Fahn (1995) adalah pucuk yang termodifikasi,karena menunjukan beberapa perubahan dalam pengaturan apeks pucuk. Bunga dianggap ranting yang bersumbu pendek dengan daun yang merapat dan memiliki bentuk khas sesuai fungsinya.

Empat bagian utama dari bunga (dari luar ke dalam) adalah sebagai berikut: a). kelopak bunga atau calyx, b). mahkota bunga atau corolla yang biasanya tipis dan dapat berwarna-warni untuk memikat serangga yang membantu proses penyerbukan;c) alat kelamin jantan atau androecium berupa benang sari; d) alat kelamin betina atau gynoecium berupa putik. Putik (pistilum) adalah alat kelamin betina, putik terdiri dari bakal buah (ovarium), tangkai putik (stilus) dan kepala putik (stigma). Keseluruhan putik disebut ginasium (gynaecium) di dalam ovarium terdapat bakal biji (ovulum) (Wardhini dan Iriawati,2014)

Tanaman betina biasanya memiliki bunga pistillat, meski jarang bisa menghasilkan bunga biseksual (hermaprodit) (Ram 1996). Pada tanaman pepaya ada terjadi perubahan jenis kelamin tanaman jantan terhadap hermaphrodit atau femaleness atau sebaliknya. Hal ini dapat 
disebabkan faktor suhu dan kelembaban ( Storey 1969; Allan et al. 1987; Saran et al. 2016). Tanaman hermafrodite, merupakan tanaman yang diharapkan petani karena bentuk buah yang dihasilkan memanjang atau silendris. Perbedaan bentuk bunga terkait dengan bentuk buah yang dihasilkan. Tanaman dengan bunga betina akan menghasilkan buah yang membulat dan bersegi, sedangkan tanaman jantan tidak menghasilkan buah.Tanaman betina atau Femaleness adalah karakter yang paling stabil, paling tidak dipengaruhi oleh variasi musim (Jimenez et al,2014)

Perkembangan bunga staminat (bunga jantan) menyerupai bunga pistillat (bunga betina) sampai dengan inisiasi benang sari selanjutnya perkembangan mengarah pada morfologi yang sangat berbeda. Pada bunga staminat kombinasi pertumbuhan yang berkerut dan berkembang kesatu tabung stamen yang sama menghasilkan tabung bunga yang panjang (Decraene dan Smets, 1999)

Pohon hermaprodit memiliki perbungaan yang panjangnya $2,5-25,0 \mathrm{~cm}$, satu poros ke enam bunga biasanya, bunga terminal utama dari tangkai primer dan sekunder yang sempurna. Bunga dari tangkai tersier dan paling bawah mungkin sempurna atau staminate (jantan). Kebanyakan tanaman hermaprodit dapat mengalami pembalikan seks atau modifikasi. Perubahan jenis kelamin terjadi, dari jantan ke betina, tapi tidak pernah dari betina ke jantan. Bunga hermaprodit dalam kasus 'elongata' memiliki ovarium memanjang yang berkembang menjadi buah yang berbentuk silindris, pir atau lonjong tergantung pada kultivar atau genotipe.Penelitian ini bertujuan untuk mengetahui perbedaan secara morfologi bagian-bagian bunga betina, hermparodit dan jantan dan inisiasi bagian dalam bunga secara sitologi.

\section{Bahan dan Metode}

Penelitian dilakukan pada bunga pepaya varietas Merah Delima yang ditanam di KP. Aripan Balai Penelitian Tanam Buah Tropika, Solok. Pengamatan terhadap bunga jantan betina dan hermaprodite elongata dan pentandria. Bahan dan alat yang digunakan adalah alkohol, parafin, safranin, malakit green. Pengamatan jaringan bunga dilakukan dengan menggunakan metode Alkohol Xylol (SAS, 1958) yang dimodifikasi serta pengamatan langsung menggunakan mikroskop streo. Pengamatan secara kuantitatif( moroflogi) bunga dilakukan dengan mengukur langsung bagian bunga baik pada bunga jantan murni, betina, jantan dari tanaman sempurna, bunga sempurna (hermaprodit) elongata dan pentandria, masing-masing jenis 20 bunga.

Pengambilan sampel untuk sitologi : sampel diambil sebanyak 10 bunga setiap masing jenis bunga (jantan, betina dan hermaprodit) langsung dimasukkan kedalam alkohol 70\%, kemudian sampel difiksasi dalam larutan FAA (formalin : asam asetat : alkohol $95 \%=50 \mathrm{ml}: 50 \mathrm{ml}$ : $900 \mathrm{ml}$ ) untuk setiap 1 liter larutan selama 24 jam. Dehidrasi dalam alkohol dengan konsentrasi $70 \%, 80 \%$, 90\%, dan 100\% berturut-turut selama $3 \mathrm{x} 30$ menit. Kemudian Dealkoholisasi bertahap dalam larutan xylol : parafin cair dengan perbandingan 1:3, 1:1, 3:1 d dengan lama perendaman masing-masing 30 menit. Kemudian direndam dalam xylol selama 1 jam. Selanjutnya infiltrasi dengan xylol: parafin dalam suhu $58^{\circ} \mathrm{C}$ selama 24 jam pencetakan (blocking) dalam parafin cair, kemudian didinginkan hingga padatan parafin dapat dipotong, pemotongan (embedding) menggunakan mikrotom dengan ketebalan 20 mikron dan sampel diletakkan pada objek gelas yang telah diolesi albumin mayer sebagai perekat .

Selanjutnya pewarnaan dilakukan dengan merendam preparat dalam pelarut dan zat warna safranin dan malakitgreen yang dimulai berturut-turut dari larutan xylol I, xylol II, alkohol $100 \%$ : alkohol $100 \%$, alkohol 96\%, alkohol $70 \%+$ safranin $1 \%$, alkohol $96 \%$, (masingmasing larutan 5 menit). Malakitgreen 0,1\% selama 5 menit, alkohol $96 \%$, aquades, alkohol 100\%, ,xylol III, xylol IV, perendaman dalam masing-masing larutan dilakukan selama 5 menit setelah xylol IV sampel ditutup dengan cover glass yang 
telah diolesi etelan canada, preparat dibiarkan kering dan dapat diamati dibawah mikroskop .

\section{Hasil dan Pembahasan}

Pengamatan langsung pada bunga jantan murni, betina, jantan dari tanaman sempurna ,bunga hermaprodit elongata dan hermaprodit pentandria terlihat pada tabel 1. Rangkaian bunga jantan dari tanaman sempurna berdiri sendiri atau tunggal berbeda dengan bunga jantan dari tanaman jantan. Ukuran bunga jantan dari tanaman sempurna (masculus) lebih besar dibandingkan dengan bunga jantan (staminate) dari tanaman jantan (murni).

Panjang mahkota bunga (corolla) berkisar 1,4-2,2 cm sedangkan bunga jantan dari tanaman jantan 0,7-1,2 cm, lebar mahkota bunga hanya berbeda sedikit lebih lebar mahkota dari bunga jantan masculus.

Tabel 1. Perbedaaan secara kuantitatif bunga jantan murni (staminate), jantan masculus, bunga hermaprodit elongata dan pentandria

\begin{tabular}{|c|c|c|c|c|c|}
\hline Karakter & $\begin{array}{c}\text { Bunga jantan } \\
\text { (masculus) }\end{array}$ & $\begin{array}{l}\text { Bunga } \\
\text { jantan } \\
\text { (staminate) }\end{array}$ & $\begin{array}{l}\text { Bunga betina } \\
\text { (femineus) }\end{array}$ & $\begin{array}{l}\text { Hermaprodit } \\
\text { Elongata }\end{array}$ & $\begin{array}{c}\text { Hermaprodit } \\
\text { Pentandria }\end{array}$ \\
\hline Rangkaian bunga & Tunggal & majemuk & tunggal & majemuk & majemuk \\
\hline $\begin{array}{l}\text { Panjang mahkota } \\
\text { (cm) }\end{array}$ & $\begin{array}{l}1,4-2,2 \\
S d 0,12\end{array}$ & $\begin{array}{l}0,7-1,2 \\
\text { Sd } 0,13\end{array}$ & $\begin{array}{l}3,5-4,9 \\
\text { Sd } 0,4\end{array}$ & $\begin{array}{c}1,8-3 \\
\text { Sd } 0,35\end{array}$ & $\begin{array}{l}4,1-5,6 \\
\text { Sd } 0,3\end{array}$ \\
\hline $\begin{array}{l}\text { Lebar mahkota } \\
(\mathrm{cm})\end{array}$ & $\begin{array}{l}\mathbf{0 , 5 - 0 , 9} \\
S d \quad 0,11 \\
\end{array}$ & $\begin{array}{c}0,4-0,7 \\
\text { Sd } 0,08\end{array}$ & $\begin{array}{l}0,9-1,5 \\
\text { Sd } 0,2\end{array}$ & $\begin{array}{l}0,7-1,0 \\
\text { Sd } 0,09 \\
\end{array}$ & $\begin{array}{l}1,4-1,7 \\
\text { Sd } 0,06 \\
\end{array}$ \\
\hline Jumlah mahkota & 5 & 5 & 5 & 5 & 5 \\
\hline Bentuk stigma & - & - & bercabang lima & $\begin{array}{c}\text { bercabang } \\
\text { lima }\end{array}$ & tidak teratur \\
\hline Panjang tube $(\mathrm{cm})$ & $\begin{array}{c}\mathbf{1 - 2} \\
S d 0,25\end{array}$ & $\begin{array}{l}1,8-2,1 \\
\text { Sd } 0,37\end{array}$ & - & $\begin{array}{l}1,1-1,5 \\
\text { Sd } 0,125\end{array}$ & - \\
\hline Diameter $t$ & $\begin{array}{c}\mathbf{3 , 7 5}-\mathbf{5 , 5} \\
S d 0,55\end{array}$ & $\begin{array}{l}1,1-4,35 \\
\text { Sd } 0,86\end{array}$ & - & $\begin{array}{r}1,9-2,4 \\
\text { Sd } 0,15\end{array}$ & - \\
\hline $\begin{array}{l}\text { Panjang } \\
\text { ovarium }(\mathrm{cm})\end{array}$ & - & - & $\begin{array}{l}1,8-2,9 \\
\text { Sd } 0,32\end{array}$ & $\begin{array}{l}1,4-2,3 \\
\text { Sd } 0,34\end{array}$ & $\begin{array}{l}1,3-2,8 \\
\operatorname{Sd} 0,24\end{array}$ \\
\hline $\begin{array}{l}\text { Diameter ovarium } \\
\text { (mm) } \\
\text { Kedudukan ovarium }\end{array}$ & - & - & $\begin{array}{l}9,91-15,95 \\
S d 0,19 \\
\text { superium }\end{array}$ & $\begin{array}{c}6,06-9,88 \\
\text { Sd } 0,12 \\
\text { superium }\end{array}$ & $\begin{array}{l}17,16-25,65 \\
\text { Sd } 0,15 \\
\text { superium }\end{array}$ \\
\hline $\begin{array}{l}\text { Panjang filament/ } \\
\text { tangkai sari }(\mathrm{mm})\end{array}$ & $\begin{array}{c}0,5-1 \\
\text { Sd } 0,1\end{array}$ & $\begin{array}{l}0,2-0,3 \\
\text { Sd } 0,03\end{array}$ & - & $\begin{array}{c}0,5-7 \\
\text { Sd } 0,17\end{array}$ & $\begin{array}{c}1-9 \\
\operatorname{Sd~} 0,11\end{array}$ \\
\hline Jumlah anther & 5 & $5-6$ & - & 10 & 5 \\
\hline \multicolumn{3}{|c|}{$\begin{array}{l}\text { Jumlah mahkota bunga semua jenis } \\
\text { bunga pepaya sama yaitu } 5 \text { helai dengan } \\
\text { warna hijau kekuningan. Pohon jantan } \\
\text { memiliki bunga jantan yang tersusun } \\
\text { menggantung pada malai yang panjangnya } \\
25-100 \mathrm{~cm} \text {. Bunga jantan berbentuk tabung } \\
\text { yang ramping dengan panjang kira-kira } 2.5 \\
\mathrm{~cm} \text {. Mahkota bunga terdiri dari lima helai } \\
\text { berukuran kecil dengan daun mahkota yang } \\
\text { berbentuk terompet dan warnanya kuning } \\
\text { cerah (Chan 1994; Villegas 1997). }\end{array}$} & $\begin{array}{l}\text { Bunga } \\
\text { mahkota }(c c \\
\text { sehingga ma } \\
\text { betina tidak } \\
\text { mahkota bur } \\
\text { dasar bunga } \\
\text { bunga betinc } \\
\text { dibandingkan } \\
\text { sempurna ( } h \epsilon \\
3,5-4,9 \mathrm{~cm} \mathrm{da} \\
\text { bunga sempu } \\
\text { lebar } 1,4-1,7 \\
\text { (stamen) bun }\end{array}$ & $\begin{array}{l}\text { jantan mer } \\
\text { rolla tube) } \\
\text { mbentuk tero } \\
\text { memiliki tab } \\
\text { ga langsung } \\
\text { Mahkota bu } \\
\text { lebih panja } \\
\text { dengan ma } \\
\text { rmaprodit) elo } \\
\text { lebar } 0,9-1,5 \\
\text { na pentandria } \\
\text { cm. Jumlah } \\
\text { a jantan murni }\end{array}$ & $\begin{array}{l}\text { iliki tabung } \\
\text { ang panjang } \\
\text { mpet. Bunga } \\
\text { ing mahkota, } \\
\text { melekat pada } \\
\text { nga (corolla) } \\
\text { g dan lebar } \\
\text { hkota bunga } \\
\text { ngata berkisar } \\
\text { cm, sedangkan } \\
\text { 1-5,6 cm dan } \\
\text { benang sari } \\
\text { bervariasi ada }\end{array}$ \\
\hline
\end{tabular}


5 dan 6 , tetapi bunga jantan dari tanaman sempurna tetap berjumlah 5. Bunga jantan murni memiliki benang sari yang lebih pendek dan rapat mengumpul ditengak poros bunga. Menurut Villegas (1997) dan Suketi (2010) perbedaan bunga hermafrodit elongata dan pentandria terletak pada jumlah benang sari dan bentuk putik. Bunga hermaprodit elongata mempunyai sepuluh benang sari yang tersusun melingkar pada bakal buah, lima bertangkai panjang dan lima lainnya bertangkai pendek.

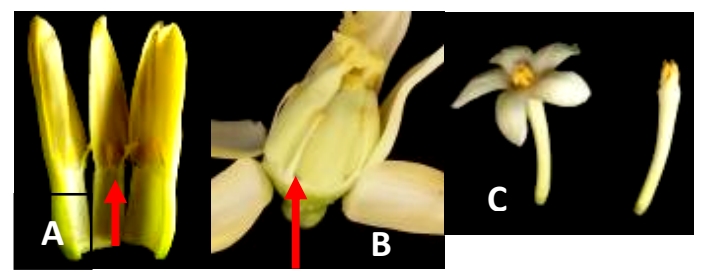

Gambar 1. Susunan benang sari bunga sempurna elongata (A) intermediet (B) dan bunga jantan (C)

Bunga sempurna (hermaprodit) terbagi tiga bunga hermaprodit elongate dan hermaprodit pentandria dan intermediet perbedaan yang tegas dari ketiga bunga tersebuat adalah jumlah benang sarinya, dimana benang sari bunga sempurna pentandria berjumlah 5 dengan panjang tangkai sari (filament) lebih panjang berkisar $0,1-1,5 \mathrm{~cm}$ sedangkan pada bunga sempurna elongate benang sari berjumlah 10 dengan panjangnya tangkai sari berkisar 0,1-0,7 $\mathrm{m}$ yang tersusun berselang seling antara yang penjang dengan yang lebih pendek (Gambar 1).Bunga intermediet memiliki benang sari 8-10 serta bentuk ovarium yang bersekat tidak beraturan.

Bagian organ betina yang paling dominan pada morfologi bunga papaya adalah bakal buah (ovarium), yang terdiri dari tangkai putik (stilus) dan kepala putik (stigma), dalam bakal putik terdapat bakal biji (ovulum). Pada bunga betina besarnya ovarium berkisar 1,8-2,9 $\mathrm{cm}$ dengan diameter $9,91-15,95 \mathrm{~mm}$ sedangkan diameter ovarium bunga sempurna elongate 6,06-9,88 $\mathrm{mm}$ lebih kecil dibanding sempurna pentandria $17,16-25,65 \mathrm{~mm}$. Menurut Storey (1986 ) ; Chan, (1994) dan
Villegas (1997) panjang bakal buahnya 2-3 $\mathrm{cm}$, mahkota bunga terdiri dari lima helai daun mahkota yang melekat di bagian dasar bunga.

Kedudukan ovarium terhadap dasar bunga maka bunga pepaya mempunyai kedudukan menumpang (superum), berdasasarkan perhiasan bunga ovarium pepaya termasuk hipoginus. Bakal buah (ovarium ) papaya memiliki ruang satu (unilokular), bakal biji (ovulum) melekat pada dinding ovarium melalui plasenta berdasarkan penmeplan plasenta maka buah papaya termasuk katagori pariental. Menurut Sedgley dan Griffin (1989) ovulum menempel pada funikulus dihubungkan oleh plasenta dan ada dua jenis plasentasi pada buah yaitu plasenta tipe parietal dan plasenta axilar. Berdasarkan ruang kepala putik bercabang lima berwarna kuning muda.

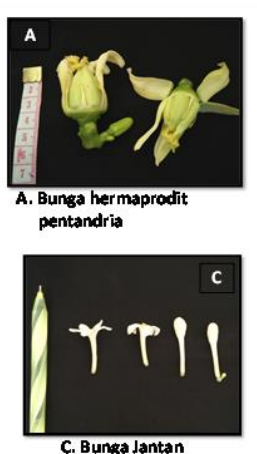

C. Bunga Jantan
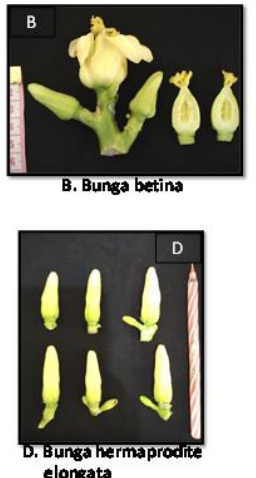

Gambar 2. Perbedaan morfologi bunga hermaprodit pentandria, bunga betina, bunga jantan dan bunga hermaprodit elongata

Gambar 2. Morfologi bunga pepaya hermaprodit pentandria, betina, bunga jantan dan hermaprodit elongata dan hermaprodit antara. Bunga hermafrodit tipe antara mempunyai mahkota bunga berjumlah lima helai, benang sari 2-10 helai yang telah mengalami perubahan bentuk serta letaknya tidak beraturan, maka putik dan benang sari bunga hermafrodit tumbuh tidak wajar dan berbentuk karpeloid atau tidak sempurna. Bakal buah berbentuk 
mengkerut dan menghasilkan buah yang bentuknya tidak beraturan Samson,1980).

Hasil pengamatan sediaan preparat dengan irisan longitudinal dibawah mikroskop disajikan pada Gambar 3. Meristem apikal tunas bunga pepaya hermafrodit teramati pada saat pengambilan sampel tunas bunga panjangnya $5-7 \mathrm{~mm}$. Tunas bunga betina dan hermafrodit sudah dapat dibedakan dengan pengamatan di bawah mikroskop hasil pengamatan tunas sudah terlihat diferensiasi bakal buah dan anter dan kepala putik (stigma).

Hasil pengukuran mikroskopis ovarium pada umur 15 hari bunga sempurna (hermaprodit A) memliki ukuran $742,86 \mu \mathrm{m}$ sedangkan ovarium bunga betina (pistilat) $745,93 \mu \mathrm{m}$.

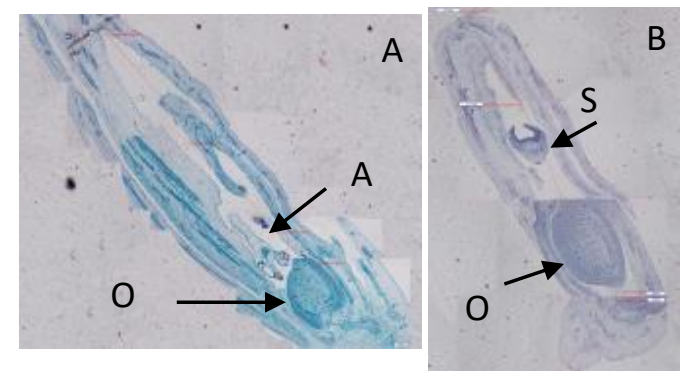

Gambar 3. Irisan longitudinal tunas bunga sempurna (A), bunga betina (B), Ov :ovarium; An: Andresium: St ;Stigma

\section{Kesimpulan}

Morfologi bunga jantan dari tanaman jantan (dioecious) ukurannya lebih kecil dari bunga jantan dari tanaman gynodioecious. Perbedaan morfologi bunga sempurna (hermaprodit) pentandria memiliki ukuran bakal buah lebih besar dibandingkan bunga hermaprodit elongate, sehingga buah yang dihasilkan lebih membulat, jumlah benang sari bunga hermaprodit pentandria 5 buah sedangkan hermaprodit elongate 10 buah. Pada umur yang sama ukuran ovarium bunga betina lebih besar dibandingkan bunga hermaprodit.

\section{Ucapan Terimakasih}

Ucapan terimakasih ditujukan kepada Ketua Jurusan dan Sekretaris Jurusan
Biologi FMIPA UNAND serta jajarannya atas fasilitas penggunaan laboratorium SPT, Sdr, Alphonsim, SSi dan Irma Yolanda yang membantu kegiatan di laboratorium.

\section{Daftar Pustaka}

Chan YK. 1994. Taksonomi pepaya.. In Chan YK, Raveendranathan P, Raziah ML, Choo ST (eds.). Penanaman Betik. MARDI. Malaysia, Kualalumpur. Malaysia. hal. 2-4

Chaves G -Bedoya, Mauricio Pulido, Erika Sánchez-Betancourt, Víctor Núñez.2009. RAPD markers for sex identification in papaya (Carica papaya L.) in Colombia. 27(2), 145-149.

FPMIPA . Struktur morfologi Organ Reproduksi pada Tumbuhan ..[diuduh tanggal februari 2018]

Jimenez Víctor M , Eric Mora- Newcomer dan Marco V. Gutiérrez-Soto. 2014. Biology of the Papaya Plant .Chapter 2. Food Security Center, University of Hohenheim, Stuttgart, Germany

Magdalita Pablito $\mathrm{M}$ and. Mercado Charles P. 2003. Determining the Sex of Papaya for Improved Production. Vegetables and Fruit / Breeding and Seed Production. Food and Fertilizer Technology Center . pp 1-14.

Ming. Ray, Qingyi Yub,dan Paul H. Moorec 2007. Review Sex determination in papaya. Seminars in Cell \& Developmental Biology. ( 18) 401-408.

Nakasone HY. 1986. Papaya. Basic flower types in Carica papaya L. p.277301. In Monselise SP (ed.). Handbook of Fruit Set and Development. CRC Press, Inc. Boca Raton, Florida

Paterson A, Felker P, Hubbell S, Ming R .2008 .The fruits of tropical plant genomics. Trop Plant Biol 1(1):319 Paull RE, Gross K, Qiu Y. 1999. Changes in papaya cell walls 
Jurnal Biologi Universitas Andalas (J. Bio. UA.)

7(1) - Maret 2019: 21-26 (ISSN : 2303-2162)

during fruit ripening. Postharv.

Biol. Tech . 16:78-89.

Samson JA. 1980. Tropical Fruits. 2nd Ed.

UK: Longman Inc. $336 \mathrm{p}$

SaSs, J. E. 1958. Botanical Microtechnique. Second Edition. The Iowa State University Press. Ames. Iowa.

Sedgley M, Griffin AR. 1989. Sexual Reproduction of Tree Crops. CA: Acad. Press. Inc. 378p.

Suketi K, Poerwanto R, Sujiprihati S, Sobir, Widodo WD. 2010. Analisis kedekatan hubungan antar genotipe pepaya berdasarkan karakter morfologi dan buah. J. Agron. Indonesia. 38(2): 130-137

Fahn, A. 1995. Anatomi Tumbuhan Edisi Ketiga.Gadjah Mada University Press. Yogyakarta

Ronse Decraene LP, Smets EF. 1999. The floral development and anatomy of Carica papaya (Caricaceae). Can. J. Bot 77:582-598.

Rosanti, D. 2013. Morfologi Tumbuhan. Jakarta : Erlangga.

Saran P. Lal, Ishwar Singh S dan Ravish C. 2016 . Papaya: Biology, Cultivation, Production and Uses. Taylor \& Francis Group,CRC Press. Boca Raton London New York

Storey WB. 1986. Carica papaya. p. 147157. In Halevy AH (ed). Handbook of Flowering. CRC Press, Inc. Boca Raton, Florida.

Tjitrosoepomo G. 2005. Morfologi Tumbuhan. UGM press. Yogyakarta

Villegas VN. 1997. Carica papaya L. p. 108-112. In Verheij EWM, Coronel RE (eds.). Edible Fruit and Nuts. Plant Resources of South-East Asia. (PROSEA) Foundation. Bogor. Indonesia.

Wardhini. T dan Iriawati.2014. Struktur Bunga,Bagian-bagian Bunga, dan Modifikasinya. Modul I.Bahan Ajar.Univ Terbuka. 39 hal. 